\title{
Hydrothermal treatment of Novelose 330 results in high yield of resistant starch type 3 with beneficial prebiotic properties and decreased secondary bile acid formation in rats
}

\author{
Gisela Jacobasch*, Gerhard Dongowski, Detlef Schmiedl and Katrin Müller-Schmehl \\ German Institute of Human Nutrition Potsdam-Rehbruecke, Research Group Food Chemistry and Preventive Nutrition, \\ D-14558 Nuthetal, Germany
}

(Received 23 May 2005 - Revised 28 November 2005 - Accepted 29 November 2005)

\begin{abstract}
Annealing and heat-moisture treatment (HMT) are shown to be suitable methods to increase the yield of resistant starch type 3 (RS3) from Novelose 330 by up to $75 \%$. Peak temperatures of approximately $121^{\circ} \mathrm{C}$ were used to produce to a sufficiently high thermal stability of the hydrothermal modified RS3 products for a wide range of applications. HMT significantly increased the crystallinity up to $40 \%$. An in vivo feeding experiment with Wistar rats showed that fermentation of Novelose 330 dominated in the proximal colon, but degradation of HMT-Novelose was more dominant in the distal colon, leading to higher butyrate concentrations in this segment of the large bowel. Large-bowel surface and crypt length increased in the proximal colon in rats fed the Novelose 330-containing diet. In contrast, after the intake of HMT-Novelose, maximal values were found in the distal segment. The lower $\mathrm{pH}$ and higher butyrate concentration of the caecal and colonic contents significantly suppressed the formation of secondary bile acids in RS3-fed rats. The formation of secondary bile acids was inhibited more strongly by HMT-Novelose than by Novelose 330. The Ki-67-immunopositive epithelial cells in the colon of RS3-fed rats indicated the establishment of an optimal balance in the dynamic process of mucosal regeneration. HMT provides a method for the economical production of a high-quality RS3 with dominating prebiotic properties in the distal colon for health-promoting applications.
\end{abstract}

Resistant starch structure: Heat-moisture treatment: Physiological effect: Short-chain fatty acid: Bile acid: Rat

The mammalian intestine is densely populated with different strains of bacterium, making it an important site for hostmicrobe interactions, which are associated with several beneficial functions. These include the growth of a bacterial population with an apathogenic composition, nutrient-processing, the regulation of intestinal angiogenesis, the development of gut-associated lymphoid tissue, the induction of mucosal immunity, etc. (Barcenilla et al. 2000; Macfarlane \& Cummings, 2002; Spahn \& Kucharzic, 2004).

Specific health-promoting mechanisms of bacterium-host interactions have evolved in the anaerobic milieu of the large bowel, in which butyrate production by bacterial fermentation plays a particularly crucial role. The caecum, colon and rectum are the principal sites in the intestine where the metabolism of mucosal epithelial cells is strongly connected with that of bacteria. Butyrate is the essential energy source for colonocytes and is the substrate for de novo lipogenesis (Roediger, 1982; Zambell et al. 2003). Furthermore, SCFA act as signal metabolite in the homeostasis of colonocytes, regulating the balance between proliferation, differentiation and apoptosis (Velázquez et al. 1996b; McCullough et al. 1998). Additionally, butyrate can induce anti-inflammatory, anticarcinogenic and immunosuppressive effects in vivo, illustrating the importance and effectiveness of butyratemediated mechanisms from the host defences against potentially toxic luminal compounds. (Velázquez et al. 1996a; Andoh et al. 2003). An interaction with butyrate-specific elements of multiple genes causes this fermentation product to induce the expression of many regulatory proteins, for example p21, cyclin D3, protein kinase $C-\delta$, mitochondrial 3-hydroxy-3-methylglutaryl-CoA-synthase and glutaminase (Siavoshian et al. 2000; Iacomino et al. 2001; Tabuchi et al. 2002; Cherbuy et al. 2004).

Among the amylolytic butyrate producers, strains of Eubacterium are the most important bacteria. A precondition to optimise their growth is a sufficient starch supply in the large bowel lumen. However, the distal colon and rectum are the regions with the most limited starch sources of carbon and energy for bacterial growth, and butyrate concentrations in these regions of the gut are often very low; consequently, these are sites of widespread diseases such as ulcerative colitis and cancer.

This problem can be overcome without an additional energy load to the organism by an intake of prebiotic resistant starch

Abbreviations: DCA, deoxycholic acid; HDCA, hyodeoxycholic acid; HMT, heat-moisture treated/treatment; LCA, lithocholic acid; MCA, muricholic acid; RS, resistant starch; RS3, resistant starch type 3.

* Corresponding author: Professor Dr Gisela Jacobasch, fax +49 33200 88444, email G.K.Jacobasch@t-online.de 
(RS). This type of starch has a reduced caloric content and decreases insulin secretion compared with rapidly digested starches (Ranhotra et al. 1996). RS is defined as the sum of starch and products of starch degradation not absorbed in the small intestine of healthy individuals, because it cannot be hydrolysed by pancreatic enzymes (Englyst et al. 1992). From the four types of RS classified (1, physically inaccessible starch from whole or partly milled grains; 2 , native starches; 3 , retrograded starches; 4, chemically modified starches), RS3 has the best prebiotic properties (Asp et al. 1996).

In general, RS3 is produced from gelatinised debranched starches by retrogradation (Eerlingen \& Delcour, 1995). Gelatinisation destroys the crystalline structure of the starch granule. During recrystallisation, microcrystalline filaments aggregate as double helices and form a tightly packed crystalline network stabilised by $\mathrm{H}$ bonding (Wu \& Sarko, 1978). The butyrogenic properties of RS3 products differ significantly because the length of 1,4- $\alpha$-D-glucans influences the retrogradation and, consequently, the quality of RS3 products. Chain lengths with a degree of polymerisation of about 20-35 units of glucose are optimal not only for a high output of heat-stable butyrogenic RS3, but also for a high proportion of crystallinity with an X-ray diffraction pattern of B-type structure and a low proportion of colloidal inhomogeneity (Pfannemüller, 1987; Eerlingen et al. 1994; Schmiedl et al. 2000). The biotransformation of sucrose to $1,4-\alpha$-D-glucans catalysed by the amylosucrase of Neisseria polysaccharea accomplishes this requirement, but this procedure is not industrially used (Büttcher et al. 1997).

A higher yield of RS3 is required for a wide range of applications. Thus, the purpose of the present study was to increase the yield of RS3 in the commercial type 3 RS product Novelose 330 by hydrothermal methods such as annealing and heat-moisture treatment (HMT). Proceeding on the assumption that both granular starch and RS3 are crystalline starch types, the methods of annealing and HMT may be promising strategies to reach this goal by optimising processing conditions. The quality of the RS3 products obtained (thermal stability, crystalline structures, fermentation properties) were characterised with respect to resistant structures. Microbial RS3 breakdown and the influence of Novelose 330 and HMT-Novelose on bile acid turnover, secondary bile acid formation and biological activities were investigated in comparative in vivo studies with rats.

\section{Materials and methods}

\section{Hydrothermal treatment of Novelose 330}

Novelose $330^{\circledR}$ was obtained from National Starch \& Chemical (Bridgewater, NJ, USA).

Annealing. Samples of Novelose 330 were weighed into glass vials and hydrated with ionised water to obtain moisture contents of 70 and $80 \%$ (w/w). The vials were tightly capped and equilibrated overnight, after which the samples were tempered at 85 and $90^{\circ} \mathrm{C}$ for 4,6 and $24 \mathrm{~h}$. Annealing was stopped by cooling for $3 \mathrm{~h}$ at room temperature, and samples were freeze-dried.

Heat-moisture treatment. Starch pastes of Novelose 330 (concentration 60-90\%, w/w) were equilibrated overnight and then autoclaved for $1 \mathrm{~h}$ at different temperatures between 105 and $121^{\circ} \mathrm{C}$ before being cooled for $2 \mathrm{~h}$ at room temperature. Finally, the HMT-Novelose was frozen for $1 \mathrm{~h}$ at $-20^{\circ} \mathrm{C}$ and freeze-dried.

\section{Differential scanning calorimetry}

Differential scanning calorimetry experiments were performed with a DSC-120 (Seiko Instruments, Neu Isenburg, Germany), using indium for calibration. The samples were weighed into silver pans, and water was added to obtain a $\mathrm{DM}-\mathrm{H}_{2} \mathrm{O}$ ratio of 1:5 (w/w). The samples were sealed and heated from 10 to $220^{\circ} \mathrm{C}\left(4^{\circ} \mathrm{C} / \mathrm{min}\right)$. A pan filled with water was used as reference. The onset, peak and conclusion temperatures $\mathrm{T}_{\mathrm{o}}, \mathrm{T}_{\mathrm{p}}$, and $\mathrm{T}_{\mathrm{c}}$, as well as conversion enthalpy, $\Delta \mathrm{H}$, were calculated by integration using Seiko software (SSC 5200H; Seiko Instruments, Tokyo, Japan).

\section{$X$-ray diffraction}

The X-ray wide-angle scattering curves were recorded for each starch sample using a microcomputer-controlled, modified five-slit diffractometer (Freiberg Präzisionsmechanik, Freiberg, Germany) in transition. The operating conditions were $\mathrm{CuK}_{\text {oradiation }}$ generated in a five focus tube at $(1.2 \mathrm{~kW})$, and scattering region $0.42^{\circ} \leq 2 \theta \leq 0.52^{\circ}$ ( $2 \theta$ scattering angle). The crystallinity of the RS3 samples was determined according to the procedure described by Gernat et al. (1993).

\section{Rat experiment}

Young male Shoe-Wistar rats (Tierzucht Schönwalde GmbH, Schönwalde, Germany) weighing 203.4 (SD 12.5) g were randomly divided into three groups of five animals each and kept in a temperature-controlled environment $\left(22 \pm 2^{\circ} \mathrm{C}\right)$ with a normal $12 \mathrm{~h}$ light $-12 \mathrm{~h}$ dark cycle. All rats were fed the control diet for $7 \mathrm{~d}$ after arrival. They were then fed the control diet or the diets supplemented with the same amount of RS3 in the form of either Novelose 330 or HMT-Novelose for $25 \mathrm{~d}$. The composition of the diets is given in Table 1 . The HMT-Novelose was the starch produced with the highest RS3 content. The rats had free access to food and water during the experiment.

After $25 \mathrm{~d}$ of consuming the diets, the rats were killed by $\mathrm{CO}_{2}$ asphyxiation, and selected organs (e.g. caecum, colon), as well as the contents of caecum, colon and faeces, were collected, prepared and immediately stored at $-20^{\circ} \mathrm{C}$ for analysis. The colon was divided into the proximal and the distal parts, and tissue was taken for histological investigations.

The rat experiment was carried out in the Max-Rubner-Laboratory of the German Institute of Human Nutrition, PotsdamRehbruecke. The experimental protocol was performed according to international and national guidelines. All treatments and diets were formally approved by the Animal Welfare Committee of the State Brandenburg (Ministry for Agriculture, Environmental Protection and Regional Planning), Germany.

\section{Analytical methods}

The total starch content of diets was determined enzymatically using amyloglucosidase after starch extraction with 
Table 1. Composition of the diets used $(\mathrm{g} / \mathrm{kg})$

\begin{tabular}{lrcc}
\hline Diet ingredient & Control & Novelose 330 & HMT-Novelose \\
\hline Wheat starch* & 600 & 352 & 470 \\
RS3 preparation† & 0 & 248 & 130 \\
Casein $\ddagger$ & 180 & 180 & 180 \\
Sunflower-seed oil§ & 100 & 100 & 100 \\
Microcrystalline cellulose\| & 50 & 50 & 50 \\
Mineral mixtureף & 50 & 50 & 50 \\
Vitamin mixture $^{\star *}$ & 20 & 20 & 20 \\
\hline
\end{tabular}

RS3, Resistant starch type 3; HMT, heat-moisture-treated.

*Hermann Kröner GmbH Co. KG, Ibbenbüren, Germany (RS-free).

† Novelose 330 (404g RS3/kg; National Starch \& Chemical; Bridgewater, NJ, USA) or HMT-Novelose $(771 \mathrm{~g} \mathrm{RS} 3 / \mathrm{kg})$.

‡Dauermilchwerk Peiting GmbH, Landshut, Germany.

$\S$ Thomy GmbH, Karlsruhe, Germany.

II Vivapur (Heweten 20; Rettenmaier \& Söhne GmbH \& Co., Ellwangen-Holzmühle Germany).

- Altromin $\mathrm{GmbH}$, Lage, Germany. The composition of the mineral mixture was (g/kg): Ca, 185; P, 145; Na, 88; Mg, 16; K, 140; S, 34; Cl, 72; Fe, 4; Mn, 2; Zn, 0.6; Cu, 0.16; I, 0.008; Mo, 0.2; F, 0.08; Se, 0.004; Co, 0.002.

** Altromin $\mathrm{GmbH}$, Lage, Germany. The composition of the vitamin mixture was $(\mathrm{mg} / \mathrm{kg})$ : vitamin $\mathrm{A}, 225$; vitamin $\mathrm{D}_{3}, 500 \mathrm{IU}$; vitamin $\mathrm{E}, 8000$; vitamin $\mathrm{K}_{3}, 10$; vitamin $B_{1}, 1000$; vitamin $B_{2}, 1000$; vitamin $B_{6}, 750$; vitamin $B_{12}$, 1.5; niacin, 2500 pantothenic acid, 2500; folic acid, 500; biotin, 10; choline chloride, 50000 ; $p$-aminobenzoic acid, 5000; myo-inositol, 5000; vitamin C, 20; methionine, 3500.

$1 \mathrm{M}-\mathrm{NaOH}$. The glucose released was analysed with the hexokinase/glucose-6-phosphate dehydrogenase kit from Boehringer (Mannheim, Germany). RS was measured in vitro by a modified Englyst method (Englyst et al. 1992) after hydrolysis of the digestible starch and extraction of the hydrolysis products with $80 \%$ ethanol. The RS was dissolved in $1 \mathrm{M}$ $\mathrm{NaOH}$, hydrolysed with amyloglucosidase and determined enzymatically as released glucose using the kit described above.

SCFA were analysed in the intestinal contents and in freshly taken faeces by GC as previously described (Sembries et al. 2003). The extraction and purification procedures of freezedried intestinal contents and faecal materials, and of analysis of the bile acids by HPLC using pre-column derivatisation with 4-bromomethyl-7-methoxycoumarin and fluorescence detection, are given elsewhere (Dongowski et al. 2003). The $\mathrm{pH}$ values were measured in the homogenised suspensions of caecal and colonic contents (material- $\mathrm{H}_{2} \mathrm{O}, 1: 5$, w/v) using a glass electrode.

\section{Experimental procedure for histological investigations}

The first centimetre of the proximal colon and the last centimetre of the distal colon were washed in ice cold PBS, fixed in $4 \%$ formalin for $24 \mathrm{~h}$ and washed for $24 \mathrm{~h}$ under tap water. Afterwards, the specimens were dehydrated and embedded in paraffin wax.

For determination of crypt length, tissues sections $(2 \mu \mathrm{m})$ from the proximal and distal colon were stained with haematoxylin and eosin after rehydration. The crypt length was determined as the distance between the basal side of the lamina epithelialis at the bottom of the crypt and the apical side of the lamina epithelialis at the top of the crypt.

To evaluate cell proliferation, Ki-67 was immunohistochemically detected on rehydrated sections from the proximal and distal colon. Briefly, the slides were immersed twice for 5 min in boiling Target Retrieval Solution (Chem Mate;
Dako, Hamburg, Germany). After the slides had been treated with $3 \% \mathrm{H}_{2} \mathrm{O}_{2}$ for $10 \mathrm{~min}$, the sections were incubated with a mouse monoclonal antibody against Ki-67 (MIB-5; Dianova, Hamburg, Germany) in a 1:100 dilution with Antibody Diluent (Dako) overnight at $4^{\circ} \mathrm{C}$ in a humid chamber. The secondary antibody, biotin-conjugated rabbit anti-mouse $\operatorname{IgG}$ (Dako), was used in a 1:500 dilution for $30 \mathrm{~min}$ at room temperature, followed by incubation with a streptavidin-biotin-horseradish peroxidase complex (StreptABComplex/HRP; Dako) and visualisation via diaminobenzidine (Dako). Each step was followed by thorough rinsing with PBS three times for $5 \mathrm{~min}$.

Microscopy and morphometry were carried out using a light microscope (E1000; Nikon, Düsseldorf, Germany) in combination with camera model CCD-1300CB (Vosskuehler, Düsseldorf, Germany) and the digital analysis system Lucia Image 4.61 (Nikon).

\section{Statistics}

A randomised, complete block design was used in the present study. Statistical analysis was performed using Statistical Package for Social Sciences software SPSS 11.0 (SPSS Inc., Chicago, IL, USA). All values are given as mean values and standard deviations. Data were analysed by one-way ANOVA, and differences between the Novelose groups and the control group were evaluated by Dunnett's $t$ test and Dunnett's T3 test for multiple post hoc comparisons. Differences with a value $P<0.05$ were considered significant.

\section{Results}

\section{Hydrothermal steps to produce RS3 in high yield and quality}

Novelose 330 is a retrograded RS3 generated from the hydrolysed products of corn starch. This commercial product contains $40.4 \%$ RS3. It is composed of a low molecular fraction with a chain length of $\alpha-1,4-D$-glucans of between 10 and 40 glucose units and a larger amount of higher-molecular-weight polymers. As in granular starches, RS3-containing products represent partial crystalline systems. Therefore, hydrothermal procedures have been used to increase the yield of RS3 and to achieve a high stability of the resistant structures of Novelose. The two hydrothermal methods used in this study were annealing and HMT.

Important characteristics that had to be considered for successful annealing were water in excess and optimal temperatures, which are lower than the differential scanning calorimetry peak temperature of gelatinisation. The highest RS content, of $67 \%$ RS3, was obtained after tempering at $90^{\circ} \mathrm{C}$ for $24 \mathrm{~h}$ (Table 2). The increase in RS3 was less with shorter heating times and with lower temperatures. The results of differential scanning calorimetry investigations and X-ray analysis indicated that annealing enhanced the resistant structures of Novelose 330 but did not change the X-ray diffraction pattern.

Lower moisture content and higher temperatures compared with the annealing process are characteristic features of HMT. The highest RS3 yield of $74.8 \%$ was obtained by using an $80 \%(\mathrm{w} / \mathrm{w})$ starch paste with autoclaving at $121^{\circ} \mathrm{C}$. Lowering the temperature and increasing the moisture content both 
Table 2. Resistant starch content $(\mathrm{g} / \mathrm{kg})$ of Novelose 330 and Novelose after annealing and heat-moisture treatment*

(Means of 3-5 measurements with standard deviations)

\begin{tabular}{lccc}
\hline Preparation & Mean & SD & $n$ \\
\hline Novelose 330 & 404 & 42 & 3 \\
Annealed Novelose & 674 & 13 & 5 \\
Heat-moisture-treated Novelose & 771 & 33 & 5 \\
\hline
\end{tabular}

* For details and procedures, see Table 1 and pp. 1064-1065.

reduced RS3 output. HMT enhanced the stability of resistant structures and abolished the first endotherm in differential scanning calorimetry (Table 3 ). In contrast to annealing, an increase in transition enthalpy was observed. Although both Novelose 330 and HMT-Novelose possessed two endotherms, with peak temperatures of 110.8 and $124.8^{\circ} \mathrm{C}$, and 114.8 and $128.1^{\circ} \mathrm{C}$, respectively, HMT gave only one endotherm, with a peak temperature of $124 \cdot 0^{\circ} \mathrm{C}$. From the increase in transition enthalpy, $\Delta \mathrm{H}$, induced by HMT, it can be assumed that more material exists in the crystalline state. X-ray diffraction analysis confirmed this conclusion (Fig. 1).

Three structural characteristics were determined from the X-ray diffraction diagrams: the degree of crystallinity, the crystalline types and the dimension of colloidal inhomogeneities. Crystallinity describes the portion of crystallinity of the total system, which can reach a maximum value of $50 \%$ in RS3 products. Crystallinity was calculated from the X-ray diffraction pattern using the equation $\mathrm{X}_{\mathrm{c}}=\mathrm{A}_{\mathrm{c}} /\left(\mathrm{A}_{\mathrm{c}}+\mathrm{A}_{\mathrm{a}}\right)$, where the area below the amorphous diffraction diagram is $\mathrm{A}_{\mathrm{a}}$, and $\mathrm{A}_{\mathrm{c}}$ corresponds to the area below the crystalline peaks. HMT significantly enhanced the crystalline part from $25.3 \%$ in Novelose 330 to $40.0 \%$ in HMT-Novelose, and this increase in crystallinity was accompanied by a decrease in colloidal inhomogeneity. The crystallinity correlated with the temperature stability of the RS3 products but did not correlate with its structural type. Although Novelose 330 was exclusively composed of type B crystals, HMT-Novelose included predominantly B structures but additionally a small proportion of type A crystals.

Both hydrothermally treated RS3 products of Novelose 330 have been tested in twelve human subjects. All the subjects confirmed good sensory properties and a palatable mouth feeling (data not shown). The increased RS3 content and higher temperature stability of the annealed or HMT-RS3 products may open wider fields for the application of modified Novelose 330 in the food industry.

\section{Body weight gain and net weights of the large bowel}

All rats fed the test diets were in good health and grew constantly throughout the experimental period. At the end of the study, the rise in mean body weights of all the rats was 121.5 (SE 10.8) g. Table 4 shows the weights of the whole caecum and colon. An intake of either of the RS3 products resulted in a significant increase in caecum weight; this effect was more pronounced in rats consuming Novelose 330 than in rats consuming HMT-Novelose. Colon weights tended to rise only slightly in rats fed the HMT-Novelose-supplemented diet $(P=0.055)$.

More evidence on diet-mediated changes of the large bowel contents resulted from a comparison of the wet contents of the different segments of the intestine. As expected, the increase in caecal content in the Novelose 330-fed rats was larger than that in animals given HMT-Novelose. The weight of the proximal colon contents of Novolose-fed rats was significantly different from that of both control and HMT-Noveloseconsuming animals. However, the weight of contents from the distal colon was significantly higher in rats fed HMT-Novelose. These data show that Novelose 330 is fermented a little better in the upper part of the large bowel, whereas the doubled biomass in the distal colon reflects the good fermentation of HMT-Novelose (Table 4) in this region of the colon.

\section{Short-chain fatty acids}

The consumption of both RS3 products significantly affected the concentration of SCFA in the large bowel, but to different extents in the three intestinal segments (Table 5). In the caecum, the main site of bacterial fermentation, there was an increase in total SCFA concentration of approximately $42 \%$ with Novelose 330 compared with approximately $33 \%$ for HMT-Novelose. The values for these two RS3 products are not significantly different from each other. Acetate was the dominant SCFA in all segments of the large intestine, with a molar proportion of approximately $73 \%$.

The consumption of both RS3 products resulted in a significant increase in butyrate concentration in all regions of the intestine examined. In the caecum and proximal colon, the

Table 3. Thermal stability of Novelose 330 (N 330), annealed Novelose (AN-N) and heat-moisture-treated Novelose (HMT-N) measured by differential scanning calorimetry*

(Means and standard deviations, $n 3$ )

\begin{tabular}{|c|c|c|c|c|c|c|c|c|c|c|c|c|c|c|c|c|}
\hline \multirow{2}{*}{ Preparation } & \multicolumn{8}{|c|}{ 1st endotherm } & \multicolumn{8}{|c|}{ 2nd endotherm } \\
\hline & \multicolumn{2}{|c|}{$\mathrm{T}_{0}\left({ }^{\circ} \mathrm{C}\right)$} & \multicolumn{2}{|c|}{$\mathrm{T}_{\mathrm{p}}\left({ }^{\circ} \mathrm{C}\right)$} & \multicolumn{2}{|c|}{$\mathrm{T}_{\mathrm{c}}\left({ }^{\circ} \mathrm{C}\right)$} & \multicolumn{2}{|c|}{$\Delta \mathrm{H}(\mathrm{mJ} / \mathrm{mg})$} & \multicolumn{2}{|c|}{$\mathrm{T}_{0}\left({ }^{\circ} \mathrm{C}\right)$} & \multicolumn{2}{|c|}{$\mathrm{T}_{\mathrm{p}}\left({ }^{\circ} \mathrm{C}\right)$} & \multicolumn{2}{|c|}{$\mathrm{T}_{\mathrm{c}}\left({ }^{\circ} \mathrm{C}\right)$} & \multicolumn{2}{|c|}{$\Delta \mathrm{H}(\mathrm{mJ} / \mathrm{mg})$} \\
\hline N 330 & $104 \cdot 2$ & 0.38 & $110 \cdot 8$ & 0.55 & 113.5 & 0.86 & 1.0 & 0.17 & $113 \cdot 7$ & 0.45 & $124 \cdot 8$ & 0.56 & $134 \cdot 2$ & 0.68 & 4.5 & 0.42 \\
\hline AN-N & $106 \cdot 8$ & $7 \cdot 30$ & $114 \cdot 8$ & $1 \cdot 30$ & $122 \cdot 5$ & 1.90 & 1.5 & 0.30 & $117 \cdot 5$ & 3.00 & $128 \cdot 1$ & 0.20 & $136 \cdot 3$ & 0.70 & $4 \cdot 7$ & 0.30 \\
\hline HMT-N & & & & & & & & & $111 \cdot 6$ & 0.25 & $124 \cdot 0$ & 0.80 & $137 \cdot 1$ & $0 \cdot 10$ & $11 \cdot 7$ & $0 \cdot 70$ \\
\hline
\end{tabular}

$T_{0}$, onset temperature; $T_{p}$, peak temperature; $T_{c}$, conclusion temperature; $\Delta H$, conversion enthalpy.

${ }^{*}$ For details and procedures, see pp. 1064-1065. 


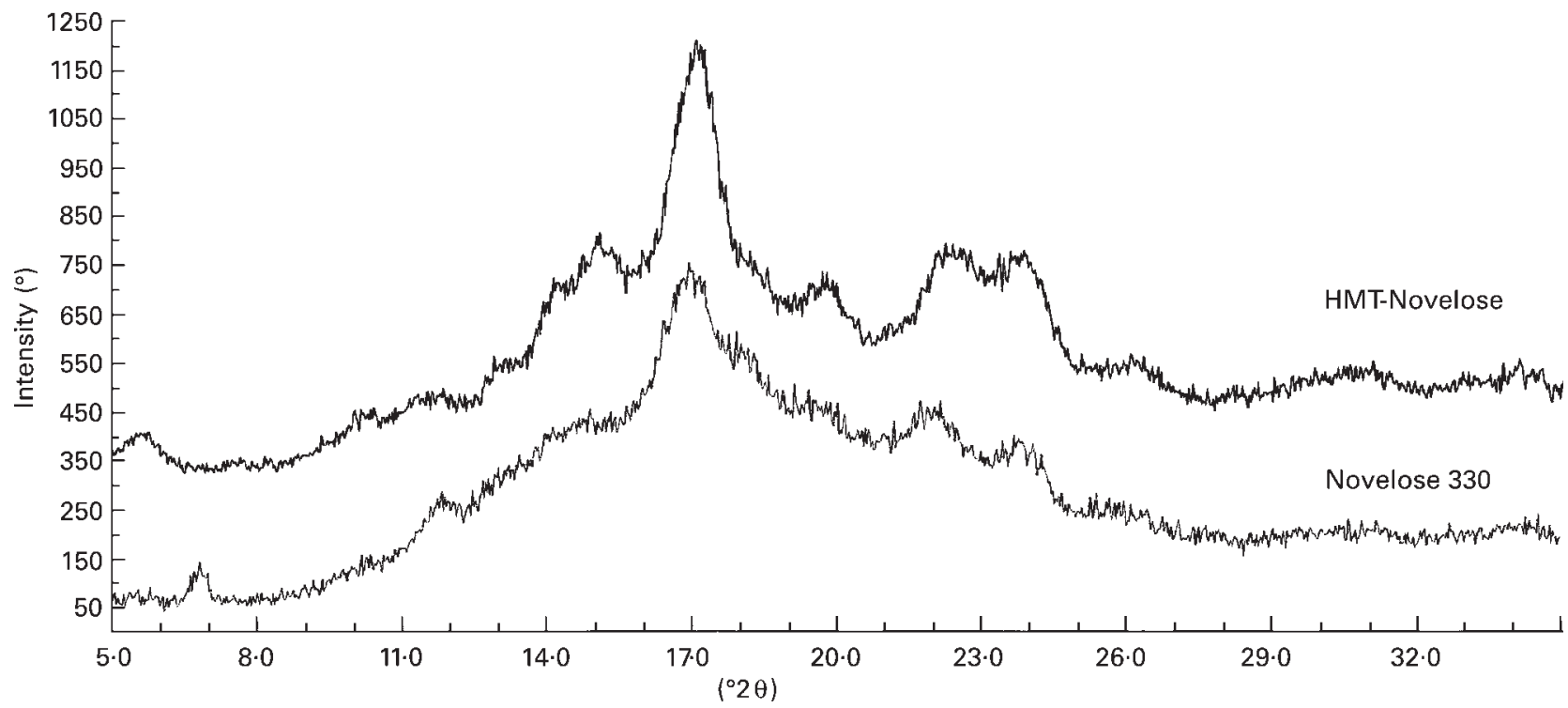

Fig. 1. X-ray spectrum of Novelose 330 and heat-moisture-treated Novelose.

two starches had similar effects. However, for distal colon and faecal samples, the butyrate concentration was significantly higher in rats fed HMT-Novelose than in rats fed Novelose 330. The concentration of butyrate fell by $75 \%$ between the caecum and faeces in the control rats, but the fall was less marked in rats fed Novelose $330(45 \%)$ and was only $13 \%$ lower in rats fed HMT-Novelose (Fig. 2). As a result, the concentration of butyrate in the distal colon was 3.8 times greater in rats fed HMT-Novelose than in control animals, and 5.3 times higher in the faeces when compared with the control rats.

The elevated SCFA concentrations in the faeces of rats fed Novelose 330 and the higher concentrations in rats fed HMTNovelose shows that an exchange of $10 \%$ starch with a butyrogenic RS3 in the diet is sufficient to provide enough substrate for bacterial fermentation in the distal colon and rectum.

These data suggest that Novelose 330 is preferentially fermented in the upper part of the large bowel but that HMTNovelose favours SCFA production in the distal colon. The

Table 4. Caecum and colon weights with contents of rats fed the control diet or a diet containing Novelose 330 (N 330) or heat-moisture-treated Novelose (HMT-N) for $25 \mathrm{~d}^{*}$

(Means with standard deviations, $n 5$ )

\begin{tabular}{|c|c|c|c|c|c|c|}
\hline \multirow[b]{2}{*}{ Group } & \multicolumn{2}{|c|}{ Control } & \multicolumn{2}{|c|}{ N 330} & \multicolumn{2}{|c|}{ HMT-N } \\
\hline & Mean & SD & Mean & SD & Mean & SD \\
\hline \multicolumn{7}{|c|}{ Tissue + contents $(\mathrm{g})$} \\
\hline Caecum & $3.90^{\mathrm{a}}$ & 0.529 & $7 \cdot 83^{b}$ & 0.545 & $5 \cdot 71^{c}$ & 0.290 \\
\hline Colon & 3.34 & 0.690 & 3.69 & 0.671 & $4 \cdot 25$ & 0.386 \\
\hline \multicolumn{7}{|l|}{ Contents (g) } \\
\hline Caecum & $3.43^{\mathrm{a}}$ & 0.262 & $6 \cdot 39^{b}$ & $0 \cdot 610$ & $5.08^{c}$ & 0.621 \\
\hline Proximal colon & $0.94^{a}$ & 0.123 & $1 \cdot 23^{b}$ & 0.142 & $1.07^{\mathrm{a}}$ & 0.172 \\
\hline Distal colon & $1 \cdot 15^{a}$ & 0.204 & $1 \cdot 16^{a}$ & 0.045 & $2 \cdot 24^{b}$ & 0.067 \\
\hline
\end{tabular}

a,b,c Mean values within a row with unlike superscript letters were significantly different $(P<0.05)$

${ }^{*}$ For details and procedures, see Table 1 and pp. 1064-1065. results of preliminary in vitro experiments with fresh human faecal microbial flora have also confirmed a good fermentation of HMT-Novelose (data not shown).

With the increase in SCFA concentration, the $\mathrm{pH}$ decreased in the large bowel. In comparison with the control diet, with which the $\mathrm{pH}$ did not change from 7.5 in any segment of the large bowel, consumption of Novelose 330 lowered the $\mathrm{pH}$ in caecum and proximal colon to 6.6 and 6.5 , respectively. Intake of HMT-Novelose resulted in a further fall in $\mathrm{pH}$ in the distal part of colon, to $6 \cdot 3$.

Effects of Novelose 330 and HMT-Novelose on bile acids in the large bowel and faeces

RS3 affected both the turnover of bile acids and, via the fermentation products, their enzymatic modification to secondary bile acids. This starch type will bind bile acids in the same way as starch, and as a consequence more bile acids arrived in the large intestine.

Owing to the RS3-mediated increase in caecal volume, the total bile acid concentration rose only slightly in both RS3 groups compared with the control group (Fig. 3). The proportion of caecal primary bile acids was, however, significantly higher in RS3-fed animals, and the concentration of secondary bile acids was lower (Fig. 4). With water reabsorption in the distal colon, the total bile acid concentration increased because the reabsorption rate of bile acids is minimal. This effect was lowest in HMT-Novelose-fed rats, with the distal colon in these animals exhibiting the biggest volume.

The proportion of secondary bile acids was $66 \%$ in controls but was reduced to $50 \%$ in the Novelose 330 and $44 \%$ in the HMT-Novelose group, respectively (Fig. 4). These data suggest that the intake of HMT-Novelose inhibits the colonic formation of secondary bile acids most strongly. The concentration of secondary bile acids in the proximal colon amounted to $62 \%$ in controls, $48 \%$ in Novelose-330fed but only $43 \%$ in HMT-Novelose-fed rats $(P<0.05$ for 
Table 5. SCFA in the intestinal contents and faeces ( $\mu \mathrm{mol} / \mathrm{g}$ wet weight or $\%$ ) of rats fed the control diet or a diet containing Novelose 330 (N 330) or heat-moisture-treated Novelose (HMT-N) for $25 \mathrm{~d}^{*}$

(Means and standard deviations, $n 5$ )

\begin{tabular}{|c|c|c|c|c|c|c|c|c|c|}
\hline \multirow[b]{2}{*}{ SCFA } & \multirow[b]{2}{*}{ Group } & \multicolumn{2}{|c|}{ Caecum } & \multicolumn{2}{|c|}{ Proximal colon } & \multicolumn{2}{|c|}{ Distal colon } & \multicolumn{2}{|c|}{ Faeces } \\
\hline & & Mean & SD & Mean & SD & Mean & SD & Mean & SD \\
\hline \multirow{2}{*}{ Acetate ( $\mu \mathrm{mol} / \mathrm{g}$ wet weight) } & N 330 & $58 \cdot 29^{b}$ & 2.02 & $50 \cdot 22^{b}$ & 1.02 & $42 \cdot 94^{\mathrm{b}}$ & $2 \cdot 00$ & $50 \cdot 51^{b}$ & $1 \cdot 20$ \\
\hline & HMT-N & $53.65^{\mathrm{c}}$ & 3.84 & $46 \cdot 92^{\mathrm{C}}$ & 0.83 & $48 \cdot 51^{c}$ & 1.33 & $56 \cdot 04^{c}$ & 1.86 \\
\hline Propionate ( $\mu \mathrm{mol} / \mathrm{g}$ wet weight) & Control & $10 \cdot 01$ & 0.34 & 7.56 & 0.95 & $5 \cdot 76^{\mathrm{a}}$ & 0.56 & $3 \cdot 38^{a}$ & 0.55 \\
\hline \multirow[t]{3}{*}{ Butyrate ( $\mu \mathrm{mol} / \mathrm{g}$ wet weight) } & Control & $6.92^{\mathrm{a}}$ & 0.62 & $3 \cdot 31^{a}$ & 0.62 & $2 \cdot 14^{\mathrm{a}}$ & 0.22 & $1.67^{\mathrm{a}}$ & 0.37 \\
\hline & N 330 & $10 \cdot 57^{b}$ & 1.55 & $6 \cdot 84^{b}$ & $1 \cdot 13$ & $5 \cdot 70^{\mathrm{b}}$ & 0.44 & $5 \cdot 81^{b}$ & 0.24 \\
\hline & HMT-N & $10 \cdot 21^{\mathrm{b}}$ & $1 \cdot 31$ & $6 \cdot 89^{\mathrm{b}}$ & 0.98 & $8 \cdot 10^{c}$ & 0.63 & $8 \cdot 85^{\mathrm{c}}$ & 0.93 \\
\hline \multirow[t]{3}{*}{ Total SCFA ( $\mu \mathrm{mol} / \mathrm{g}$ wet weight) } & Control & $56 \cdot 35^{\mathrm{a}}$ & 1.20 & $34 \cdot 32^{a}$ & 1.58 & $23 \cdot 83^{a}$ & $2 \cdot 26$ & $17 \cdot 03^{a}$ & $1 \cdot 17$ \\
\hline & N 330 & $79.99^{b}$ & 4.02 & $65 \cdot 48^{b}$ & 0.85 & $55 \cdot 52^{b}$ & $2 \cdot 10$ & $62 \cdot 85^{b}$ & 1.47 \\
\hline & HMT-N & $74.74^{\mathrm{b}}$ & 4.56 & $61 \cdot 21^{\mathrm{c}}$ & 0.71 & $64.97^{c}$ & 1.78 & $73 \cdot 27^{c}$ & 2.69 \\
\hline
\end{tabular}

a,b,c Mean values within a column and an individual SCFA or total SCFA with unlike superscript letters were significantly different $(P<0 \cdot 05)$.

*For details and procedures, see Table 1 and pp. 1064-1065.

HMT-Novelose compared with control and Novelose 330 groups).

Bacteria deconjugate and transform primary bile acids into secondary bile acids during passage through the large bowel, which leads to changes in the spectrum of individual bile acids (Table 6). The effect of RS3 on the concentration of muricholic acid (MCA) and cholic acid has been of special interest because these bile acids are substrates for the generation of secondary bile acids that have oncogenic potential. The concentrations of these primary bile acids were higher in RS3-fed rats. This effect was most pronounced in HMT-Novelose-consuming animals (Fig. 5). These data suggest that the two RS3-enriched diets decreased the transformation of the major primary bile acids (cholic acid, $\alpha \mathrm{MCA}, \beta \mathrm{MCA}$ ) into secondary bile acids to a different extent (Fig. 5). In the proximal and distal colon, HMT-Novelose diminished MCA transformation by $32 \%$ and to $37 \%$, but Novelose 330 by only $2 \%$ and $3 \%$ (Table 6). The level of cholic acid was $20 \%$ and $33 \%$ higher in the proximal and distal colon of the Novelose 330 group but $56 \%$ and $61 \%$ higher in HMTNovelose-fed animals compared with the controls. These data demonstrate that HMT-Novelose inhibits the formation of secondary bile acids more effectively than Novelose 330 in the large bowel.

Deoxycholic acid (DCA), lithocholic acid (LCA), hyodeoxycholic acid (HDCA) and 12-ketolithocholic acid are the dominant secondary bile acids in the large bowel of rats (Table 6, Fig. 6). Both RS3 products inhibited the formation of HDCA most strongly. Compared with controls, the

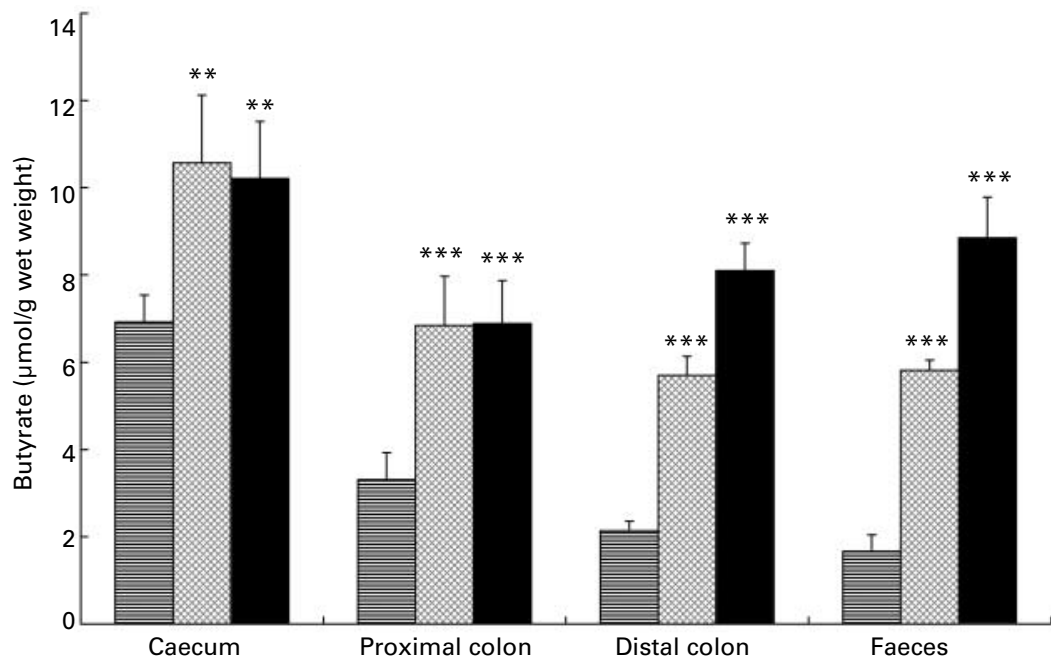

Fig. 2. Concentration of butyrate in the contents of the caecum, proximal and distal colon and in the faeces ( $\mu \mathrm{mol} / \mathrm{g}$ wet weight) of rats fed the control diet (目) or a diet containing Novelose 330 (N 330; 娄) or heat-moisture-treated Novelose (HMT-N; $\square$ ) for $25 \mathrm{~d}$ (mean values and standard deviations, $n 5$ ). Mean values were significantly different from those of the control group: ${ }^{\star \star} P<0.005,{ }^{\star \star \star} P<0.001$. For details and procedures, see Table 1 and pp. $1064-1065$. 


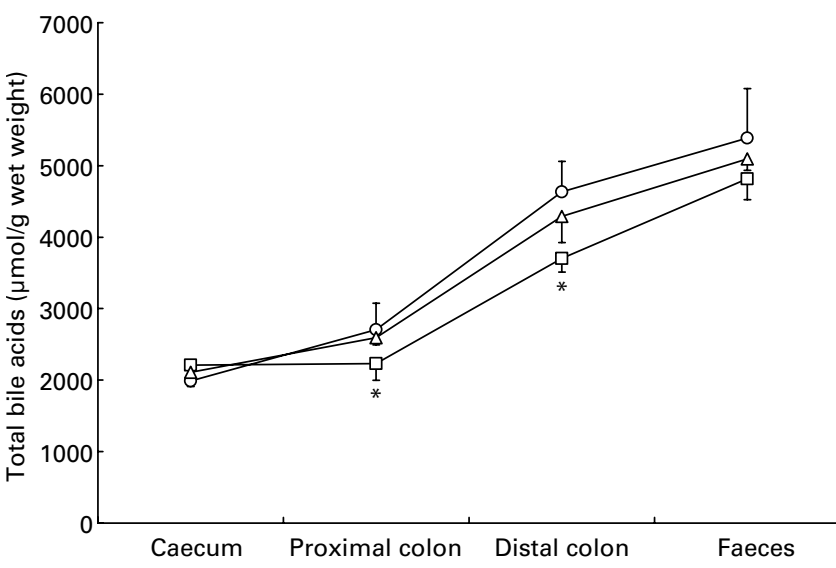

Fig. 3. Total bile acids in the luminal contents of the caecum, proximal and distal colon and in the faeces ( $\mu \mathrm{mol} / \mathrm{g}$ wet weight) of rats fed the control diet $(\bigcirc)$ and a diet containing Novelose 330 (N 330; $\square$ ) or heat-moisture-treated Novelose (HMT-N; $\Delta$ ) for $25 \mathrm{~d}$ (mean values and standard deviations, $n$ ). Mean values were significantly different from those of the control group: ${ }^{\star} P<0.05$. For details and procedures, see Table 1 and pp. 1064-1065.

HDCA concentration of the distal colon was significantly reduced, by $64 \%$ in the rats fed Novelose 330, and by $81 \%$ in the HMT-Novelose group. RS3 also significantly reduced the increase in LCA in the digesta in the large bowel. The concentrations of LCA were $40 \%$ and $32 \%$ lower than in the controls in the proximal and distal colon of the Novelose 330 group. This inhibitory effect was, however, smaller in the HMT-Novelose-fed rats. An intake of RS3 also reduced the concentration of DCA in the colon, the effect once again being greater in rats fed Novelose 330 than HMT-Novelose (Fig. 6). The concentrations of ketolithocholic acid were approximately $30 \%$ lower in the proximal and distal colon of RS3-fed rats (Table 6), and the effect of the two starch sources was similar.

\section{Crypt length and cell proliferation}

An intake of the diet enriched with Novelose 330 or HMT-Novelose stimulated colonocyte cell growth. The consumption of Novolose 330 resulted in longer crypt length in the colon, and the consumption of HMT-Novelose in particular resulted in increased crypt length in the distal colon (Table 7). Crypt-branching was frequently found in the proximal but rarely found in the distal colon of RS3-fed rats. An intake of RS3 also increased the number of crypt goblet cells; this effect was more pronounced in the distal colon in HMT-Novelose-fed rats than in rats fed Novelose 330 (Table 7). Cellular proliferative activity was determined as the number of Ki-67-positive cells. This nuclear non-histone protein is expressed in proliferating cells throughout all cell phases of the cell cycle except $G_{0}$ and early $G_{1}$, with a maximum in $G_{2}$ and $M$ phase. RS3 intake resulted in a small decrease in the number of Ki-67-labelled cells per crypt in the proximal and distal colon of Novelose 330- and HMTNovelose-fed rats (Table 7), but these differences were not statistically significant.

\section{Discussion}

The production of RS3 is currently a three-step process: debranching of native starch, gelatinisation and retrogradation under optimised conditions with respect to storage temperatures and starch concentrations for the primary starch source (Topping \& Clifton, 2001).

The critical point during this procedure is the degree of polymerisation. Polymers of fewer than ten glucose units inhibit retrogradation (Gidley et al. 1995), which significantly affects the yield of RS3. Chain-length distributions of $\alpha-1,4-\mathrm{D}$-glucans of between 10 and 40 are optimal for RS3 output, which can achieve values up to $94 \%$ (Schmiedl et al. 2000). A degree of polymerisation above 40 results in a lowering of RS3 yield. A debranching by pullulanase of amylopectin, which

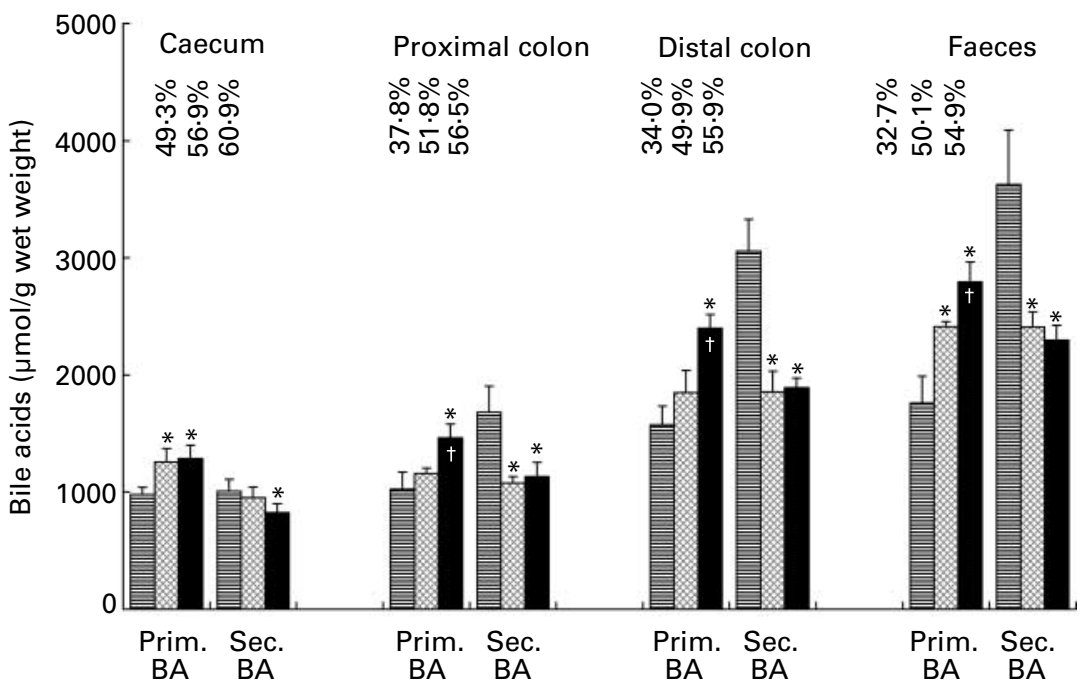

Fig. 4. Primary and secondary bile acids (BA) in the luminal contents of the caecum, proximal and distal colon and in the faeces ( $\mu \mathrm{mol} / \mathrm{g}$ wet weight) of rats fed

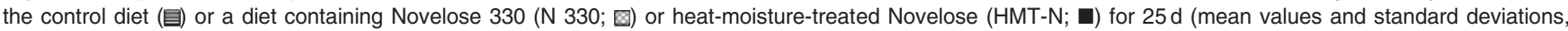
$n$ 5). Mean values were significantly different from those of the control group: ${ }^{*} P<0.05$. The mean values of the HMT-N group were significantly different from those of $\mathrm{N} 330$ group: $\dagger P<0.05$. Values above the columns show the percentage of primary (Prim.) bile acids. For details and procedures, see Table 1 and pp. 1064-1065. Sec., secondary. 
Table 6. Individual bile acids in the intestinal contents and faeces ( $\mu \mathrm{mol} / \mathrm{g}$ wet weight) of rats fed the control diet or a diet containing Novelose 330 (N 330) or heat-moisture-treated Novelose (HMT-N) for $25 \mathrm{~d}^{*}$

(Means and standard deviations, $n 5$ )

\begin{tabular}{|c|c|c|c|c|c|c|c|c|c|}
\hline \multirow[b]{2}{*}{ Bile acid } & \multirow[b]{2}{*}{ Group } & \multicolumn{2}{|c|}{ Caecum } & \multicolumn{2}{|c|}{ Proximal colon } & \multicolumn{2}{|c|}{ Distal colon } & \multicolumn{2}{|c|}{ Faeces } \\
\hline & & Mean & SD & Mean & SD & Mean & SD & Mean & SD \\
\hline \multirow[t]{3}{*}{ CA } & Control & $357.5^{\mathrm{a}}$ & 19.8 & $254.5^{a}$ & $46 \cdot 2$ & $335 \cdot 2^{\mathrm{a}}$ & $35 \cdot 3$ & $343 \cdot 6^{a}$ & $40 \cdot 3$ \\
\hline & N 330 & $449 \cdot 3^{b}$ & 35.0 & $305 \cdot 3^{b}$ & 17.4 & $446.0^{\mathrm{b}}$ & 56.6 & $503 \cdot 2^{\mathrm{b}}$ & 14.0 \\
\hline & HMT-N & $446 \cdot 9^{b}$ & 37.4 & $397 \cdot 1^{\mathrm{a}}$ & 35.0 & $540 \cdot 6^{c}$ & 35.7 & $593.4^{\mathrm{b}}$ & $66 \cdot 3$ \\
\hline \multirow[t]{3}{*}{ DCAT } & Control & 374.4 & $62 \cdot 6$ & $530 \cdot 6^{a}$ & $73 \cdot 2$ & $854.8^{a}$ & 78.7 & $987 \cdot 1$ & $127 \cdot 6$ \\
\hline & N 330 & 399.7 & 36.8 & $410 \cdot 2^{b}$ & 16.5 & $675 \cdot 5^{\mathrm{b}}$ & 71.6 & 896.5 & 38.6 \\
\hline & HMT-N & $405 \cdot 5$ & $25 \cdot 6$ & $462 \cdot 1^{\mathrm{C}}$ & 34.1 & $749 \cdot 6^{\mathrm{a}}$ & 50.0 & 878.9 & 78.4 \\
\hline \multirow[t]{3}{*}{ KDCA } & Control & $16 \cdot 2$ & 3.0 & $23.6^{a}$ & $7 \cdot 2$ & $44.9^{\mathrm{a}}$ & $14 \cdot 2$ & $54.9^{a}$ & $18 \cdot 1$ \\
\hline & N 330 & $18 \cdot 8$ & $5 \cdot 2$ & $35.5^{\mathrm{b}}$ & $5 \cdot 0$ & $73 \cdot 1^{b}$ & 11.0 & $101 \cdot 1^{\mathrm{b}}$ & $12 \cdot 9$ \\
\hline & HMT-N & $17 \cdot 2$ & $5 \cdot 8$ & $51 \cdot 0^{c}$ & 11.3 & $121 \cdot 2^{c}$ & $27 \cdot 1$ & $149 \cdot 2^{b}$ & $25 \cdot 3$ \\
\hline \multirow[t]{3}{*}{ KLCA† } & Control & $12 \cdot 1^{a}$ & 3.4 & $186 \cdot 7^{\mathrm{a}}$ & 21.3 & $409 \cdot 7^{\mathrm{a}}$ & 56.5 & $510 \cdot 5^{a}$ & $72 \cdot 0$ \\
\hline & N 330 & $16.0^{\mathrm{b}}$ & $2 \cdot 6$ & $148 \cdot 3^{\mathrm{b}}$ & $12 \cdot 0$ & $255.2^{\mathrm{b}}$ & 36.5 & $343.4^{\mathrm{b}}$ & $22 \cdot 9$ \\
\hline & HMT-N & $10 \cdot 8^{a}$ & 2.9 & $131.5^{\mathrm{b}}$ & 24.3 & $288 \cdot 6^{\mathrm{b}}$ & 28.3 & $363.7^{b}$ & $38 \cdot 1$ \\
\hline \multirow[t]{3}{*}{ CDCA } & Control & $130 \cdot 0^{\mathrm{a}}$ & 8.2 & $113.1^{\mathrm{a}}$ & 21.3 & $131 \cdot 3^{\mathrm{a}}$ & 19.3 & $126 \cdot 7^{\mathrm{a}}$ & $30 \cdot 8$ \\
\hline & N 330 & $159 \cdot 1^{\mathrm{b}}$ & 19.3 & $148 \cdot 7^{b}$ & 12.2 & $186 \cdot 2^{b}$ & 26.8 & $225 \cdot 4^{\mathrm{b}}$ & $16 \cdot 9$ \\
\hline & HMT-N & $148.4^{\mathrm{a}}$ & $14 \cdot 0$ & $171 \cdot 8^{\mathrm{b}}$ & 24.7 & $240.4^{c}$ & 19.7 & $234.9^{\mathrm{b}}$ & 32.7 \\
\hline \multirow[t]{3}{*}{ LCA† } & Control & $331.8^{\mathrm{a}}$ & $25 \cdot 8$ & $510 \cdot 4^{\mathrm{a}}$ & 75.7 & $889.5^{\mathrm{a}}$ & $60 \cdot 3$ & $1070 \cdot 5^{a}$ & 133.0 \\
\hline & N 330 & $321.0^{\mathrm{a}}$ & 38.0 & $324 \cdot 5^{\mathrm{b}}$ & 23.7 & $601 \cdot 1^{b}$ & 63.6 & $802 \cdot 0^{\mathrm{b}}$ & 37.1 \\
\hline & HMT-N & $276 \cdot 0^{b}$ & 36.3 & $397.0^{c}$ & 43.7 & $681 \cdot 6^{\mathrm{b}}$ & 17.5 & $823 \cdot 1^{\mathrm{b}}$ & $9 \cdot 1$ \\
\hline \multirow[t]{3}{*}{ UDCA } & Control & $62 \cdot 0^{\mathrm{a}}$ & $5 \cdot 8$ & $55 \cdot 6^{\mathrm{a}}$ & 12.8 & $88 \cdot 7^{\mathrm{a}}$ & 11.5 & $96 \cdot 1^{a}$ & $12 \cdot 3$ \\
\hline & N 330 & $91 \cdot 2^{\mathrm{b}}$ & 7.3 & $79 \cdot 3^{b}$ & 5.4 & $133.7^{b}$ & 17.6 & $136 \cdot 1^{a}$ & 24.7 \\
\hline & HMT-N & $80 \cdot 2^{b}$ & 11.5 & $80 \cdot 2^{b}$ & $9 \cdot 7$ & $154 \cdot 3^{\mathrm{b}}$ & 12.9 & $155.9^{c}$ & 72.0 \\
\hline \multirow{3}{*}{$\alpha \mathrm{MCA}$} & Control & $206 \cdot 7^{a}$ & 27.3 & $305 \cdot 6^{a}$ & 43.3 & $565 \cdot 2^{a}$ & $53 \cdot 2$ & $651 \cdot 5^{a}$ & 11.8 \\
\hline & N 330 & $280 \cdot 1^{b}$ & $25 \cdot 7$ & $342 \cdot 1^{a}$ & 11.7 & $600 \cdot 8^{a}$ & 76.6 & $903.8^{b}$ & 6.8 \\
\hline & HMT-N & $304.9^{b}$ & 35.0 & $404 \cdot 3^{\mathrm{b}}$ & 44.8 & $733 \cdot 3^{c}$ & $62 \cdot 1$ & $946 \cdot 2^{c}$ & $21 \cdot 2$ \\
\hline \multirow[t]{3}{*}{$\beta M C A$} & Control & $205 \cdot 2^{a}$ & 14.0 & $271.0^{\mathrm{a}}$ & 26.0 & $410 \cdot 2^{a}$ & 49.8 & $457.5^{a}$ & $65 \cdot 2$ \\
\hline & N 330 & $258.5^{\mathrm{b}}$ & 28.7 & $246 \cdot 2^{a}$ & 12.7 & $407.8^{\mathrm{a}}$ & 32.4 & $541 \cdot 7^{\mathrm{a}}$ & $24 \cdot 2$ \\
\hline & HMT-N & $298 \cdot 3^{b}$ & $26 \cdot 7$ & $358.0^{\mathrm{b}}$ & 28.9 & $607.4^{\mathrm{b}}$ & 36.7 & $761 \cdot 1^{\mathrm{b}}$ & 63.1 \\
\hline \multirow[t]{3}{*}{ HDCA $\dagger$} & Control & $290 \cdot 7^{\mathrm{a}}$ & 20.7 & $453.6^{\mathrm{a}}$ & 58.0 & $902.9^{\mathrm{a}}$ & 84.5 & $1058 \cdot 3^{\mathrm{a}}$ & 133.0 \\
\hline & N 330 & $214.9^{b}$ & 18.8 & $193 \cdot 3^{b}$ & 8.1 & $323 \cdot 2^{b}$ & 10.4 & $364 \cdot 9^{b}$ & 37.9 \\
\hline & HMT-N & $133.9^{c}$ & 16.8 & $139.9^{c}$ & 24.4 & $172 \cdot 2^{c}$ & 20.1 & $223.8^{c}$ & 29.4 \\
\hline
\end{tabular}

CA, cholic acid; DCA, deoxycholic acid; KDCA, 7-ketodeoxycholic acid; KLCA, 12-ketolithocholic acid; CDCA, chenodeoxycholic acid; LCA, lithocholic acid; UDCA, ursodeoxycholic acid; MCA, muricholic acid; HDCA, hyodeoxycholic acid.

a,b,c Mean values within a column and an individual bile acid with unlike superscript letters were significantly different $(P<0.05)$

${ }^{*}$ For details and procedures, see Table 1 and pp. 1064-1065.

† Secondary bile acid.

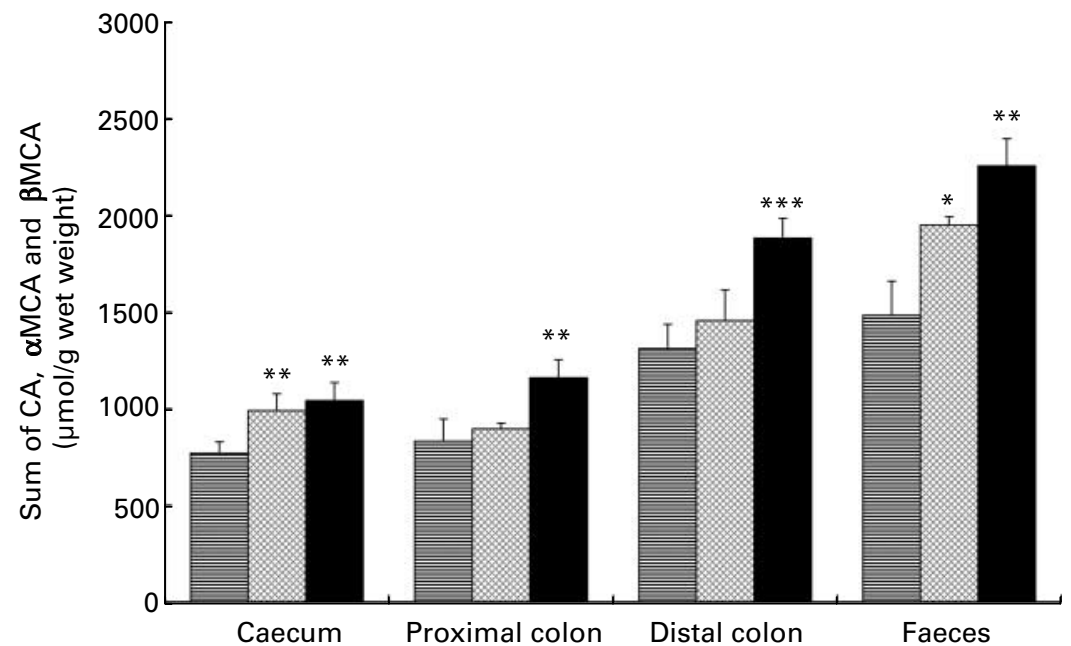

Fig. 5. Sum of cholic acid (CA), $\alpha$-muricholic acid $(\alpha \mathrm{MCA})$ and $\beta$-muricholic acid ( $\beta M C A)$ in the luminal contents of the caecum, proximal and distal colon and in the faeces ( $\mu \mathrm{mol} / \mathrm{g}$ wet weight) of rats fed the control diet (目) or a diet containing Novelose 330 (N 330; 圂) or heat-moisture-treated Novelose (HMT-N; $\square$ ) for 25 d (mean values and standard deviations, $n 5$ ). Mean values were significantly different from those of the control group: ${ }^{\star} P<0.05$, ${ }^{\star \star} P<0.005$, ${ }^{\star \star \star} P<0.001$. For details and procedures, see Table 1 and pp. 1064-1065. 


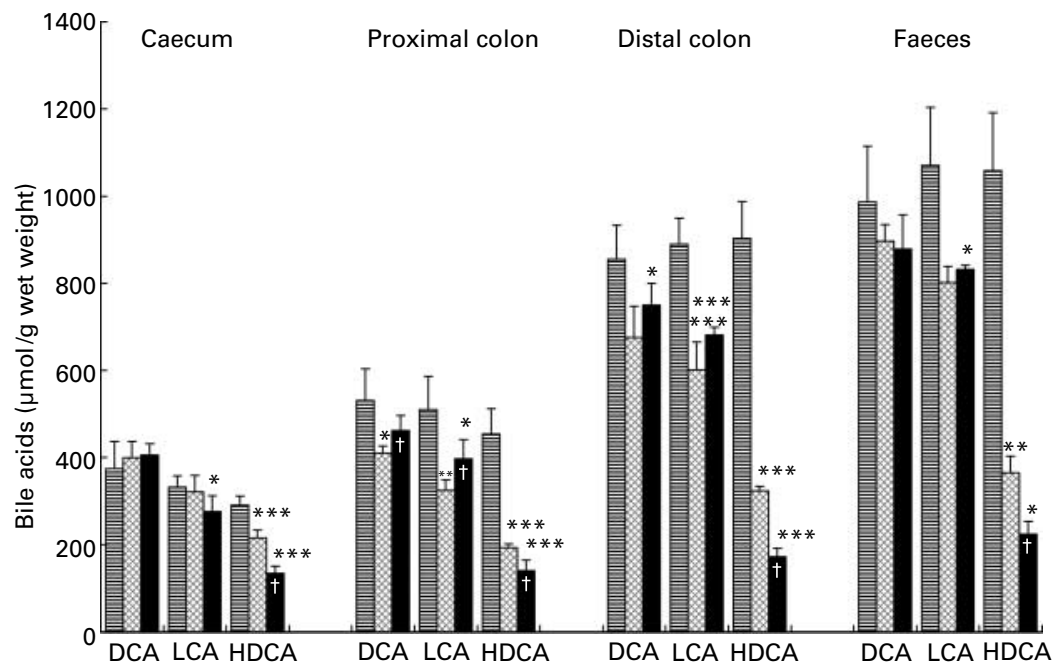

Fig. 6. Concentration of deoxycholic acid (DCA), lithocholic acid (LCA) and hyodeoxycholic acids (HDCA) in the luminal contents of the caecum, proximal and distal colon and in the faeces ( $\mu \mathrm{mol} / \mathrm{g}$ wet weight) of rats fed the control diet (目) or a diet containing Novelose 330 (N 330 ; 圆) or heat-moisture-treated Novelose (HMT-N; ) for $25 \mathrm{~d}$ (mean values and standard deviations, $n 5$ ). Mean values were significantly different from those of the control group: ${ }^{\star} P<0.05$, ${ }^{\star \star} P<0.005$, ${ }^{* \star *} P<0.001$. Mean values of the HMT-N group were significantly different from those of the $\mathrm{N} 330$ group: $\dagger P<0.05$. For details and procedures, see Table 1 and pp. 1064-1605.

contained nearly optimal side-chain lengths, resulted in a mixture of low- and high-degree polymerisation polymers, which hampered retrogradation. RS3 output from native amylose or amylopectin does not therefore normally exceed $50 \%$ (Lehmann et al. 2003).

This problem can be overcome by the hydrothermal treatment of retrograded RS3. In general, HMT and annealing prevail as methods of modifying granular starches by hydrothermal treatment (Stute, 1992). As described in this paper, both procedures can be successfully applied to increase RS3 yield in retrograded RS3 products. From the properties described and from economical considerations, it can be concluded that HMT increases RS3 output more effectively than annealing. HMT needs less water, energy and time than tempering. Annealing does not affect the X-ray diffraction pattern of Novelose 330 but it induces higher polymer interactions between both the amorphous and the crystalline matrix. From X-ray diagrams, it can be confirmed that HMT in general causes an increase in crystallinity combined with a small proportion of type A structure.

According to Gidley et al. (1995), numerous factors are known to influence the crystalline type of starches: temperature, concentration of starch solution, salts, organic molecules as well as the chain length of $\alpha-1,4-D$-glucans. Pfannemüller (1987) reported that non-dispersed amylose with a degree of polymerisation of between 10 and 12 forms type A crystals, and chain lengths with more than twelve glucose units crystallise to the B type. This may explain why more glucans with a

Table 7. Effect of resistant starches Novelose 330 and HMT-Novelose on the number of Ki-67-positive colon cells per crypt, goblet cells per crypt and bifid crypts per 100 crypts, and on crypt length in rats

(Means and standard deviations, $n 5$ )

\begin{tabular}{|c|c|c|c|c|c|c|}
\hline \multirow[b]{2}{*}{ Group } & \multicolumn{2}{|c|}{ Control } & \multicolumn{2}{|c|}{ N 330} & \multicolumn{2}{|c|}{ HMT-N } \\
\hline & Mean & SD & Mean & SD & Mean & SD \\
\hline \multicolumn{7}{|c|}{ Ki-67-positive cells/crypt } \\
\hline Proximal colon & $26 \cdot 24$ & $2 \cdot 54$ & $19 \cdot 86$ & 3.52 & 17.55 & 3.45 \\
\hline Distal colon & $21 \cdot 35$ & $3 \cdot 81$ & $18 \cdot 49$ & 3.65 & $16 \cdot 86$ & $2 \cdot 88$ \\
\hline \multicolumn{7}{|l|}{ Goblet cells/crypt } \\
\hline Proximal colon & $22 \cdot 7^{\mathrm{a}}$ & 1.41 & $33 \cdot 8^{b}$ & $2 \cdot 11$ & $33.0^{b}$ & 1.94 \\
\hline Distal colon & $27 \cdot 7^{a}$ & $2 \cdot 12$ & $31 \cdot 2^{\mathrm{a}}$ & $2 \cdot 10$ & $35 \cdot 2^{b}$ & $2 \cdot 49$ \\
\hline \multicolumn{7}{|l|}{ Crypt length $(\mu \mathrm{m})$} \\
\hline Proximal colon & $180 \cdot 3^{a}$ & $31 \cdot 10$ & $203 \cdot 9^{b}$ & $32 \cdot 01$ & $198 \cdot 5^{\mathrm{b}}$ & 41.83 \\
\hline Distal colon & $209 \cdot 3^{a}$ & 33.05 & $214 \cdot 5^{\mathrm{a}}$ & $30 \cdot 08$ & $241 \cdot 8^{b}$ & 33.73 \\
\hline \multicolumn{7}{|c|}{ Bifid crypts/100crypts } \\
\hline Proximal colon & 5 & & 8 & & 8 & \\
\hline Distal colon & 4 & & 4 & & 6 & \\
\hline
\end{tabular}

a,b,c Mean values within a row with unlike superscript letters were significantly different $(P<0.05)$. ${ }^{*}$ For details and procedures, see Table 1 and pp. 1064-1065. 
degree of polymerisation in the range $10-40$ are released by HMT of Novelose 330, which degrade predominantly to B crystals but with a smaller fraction with a degree of polymerisation of 10-12 in type A (Fig. 1). A comparison of high-performance anion-exchange chromatograms also showed that HMT increases the proportion of material with a degree of polymerisation of 8 to one of about 35 , whereas annealing does not change the pattern (Rössler et al. 2002).

Type A crystals are characterised by a monocline symmetry of the unit cell with a higher density and a lower number of water molecules (only about four per molecule). This structure delays RS3 fermentation by bacteria; therefore, the formation of a small proportion of type A crystals in HMT-Novelose may be responsible for its slower degradation, resulting in a preferred fermentation in the distal colon. Furthermore, HMT facilitates water mobility, which favours the formation of more crystalline structures in HMT-Novelose. The crystal structure of the B type is based on double-stranded helices of glucan chains, which are arranged in a right-handed, sixfold helical conformation and wound around each other in a parallel manner. The double helices are packed anti-parallel in a hexagonal unit cell (Wu \& Sarko, 1978). This RS3 structure is very well fermented.

The established preparative methods have allowed the generation, not only from Novelose 330, but also from other starch sources, of products with a high yield of RS3, high temperature stability and good fermentability for a wide range of applications that may be used to improve health (Lehmann et al. 2002, 2003; Rössler et al. 2002).

It was important to prove whether, and in what way, HMT-mediated changes in the composition of HMT-Novelose influenced fermentation activity in the large bowel. It could be shown that Novelose 330 was well fermented in the caecum and proximal colon, whereas the degradation of HMT-Novelose took place beyond the caecum and increased continuously through the colon, resulting in remarkably high SCFA and butyrate concentrations in the distal colon and rectum (faeces; Table 5). Corresponding to the high rate of HMT-Novelose fermentation in the distal colon, the growth of bacteria increased significantly, resulting in a nearly twofold increase in wet content (Table 4).

The high concentration of butyrate and the low $\mathrm{pH}$ may be important factors in protecting the mucosa of the distal colon from toxic and inflammatory damages (Figs. 4 and 6). A lower $\mathrm{pH}$ and an elevated butyrate concentration suppress the formation of secondary bile acids (Christl et al. 1997), and as a result the secondary bile acid-mediated activation of tumourpromoting effects should be lowered.This would be a benefit of the strong suppression of HDCA formation by an intake of HMT-Novelose (Fig. 6).

DCA and LCA have been particularly implicated in the promotion of colon tumorigenesis in animals and man (Reddy, 1981). The formation of these two secondary bile acids was also significantly inhibited by the consumption of HMT-Novelose but not as strongly as was seen for HDCA. DCA has been shown to cause DNA damage in colonocytes, with a subsequent induction of caspases, cyclo-oxygenase 2 promoter and the transcription factors nuclear factor- $\mathrm{\kappa} \mathrm{B}$ and activator protein-1 (Glinghammar et al. 2002; Zhang et al. 1998). Binding of bile acids to Novelose 330 and HMT-Novelose will result in less bile acid reabsorption in the terminal ileum (Abadie et al. 1994), and bile acid concentrations were highest in both the proximal and distal colon as well as in the faeces of control rats (Fig. 3). This occurs because RS3 consumption stimulates bacterial growth, producing an increase in the wet content of the digesta.

During progression from the proliferative compartment of the colonic crypt to the functional compartment, colonocytes lose their proliferative capability and acquire the characteristics of mature functional cells. The proliferative compartment in rats usually occupies some $30 \%$ of the crypt (Wright \& Alison, 1984). The dynamic balance between the generation, differentiation and apoptosis of colonocytes is mainly controlled by butyrate but, is in addition influenced by many other factors, among them secondary bile acids, which induce an extension of the proliferative compartment in the distal colon.

From the results of in vitro and in vivo studies, it can be concluded that a toxic DCA concentration can be reduced by an intake of the butyrogenic HMT-Novelose. Unphysiological, high DCA concentrations cause 'premalignant' crypt surface hyperproliferation, which can be inhibited by butyrate in vitro (Bartram et al. 1994). Velázquez et al. (1997) used ligation in the proximal colon distal to the caecum in rats to investigate the effects on proliferation under in vivo conditions after a $24 \mathrm{~h}$ intraluminal installation of butyrate and DCA. The authors concluded that low DCA concentrations $(5 \mu \mathrm{M})$ did not promote crypt surface hyperproliferation but inhibited the proliferative effect of butyrate at the crypt base.

Concentrations of $5 \mu \mathrm{M}-\mathrm{DCA}$ or higher were not found in rats fed Novelose 330 or HMT-Novelose, with a mixture of secondary bile acids occurring only in the range $2-3 \mu \mathrm{M}$. It is possible that the longer colonic crypt length (Table 7) and bigger mucosal surface of the large bowel in the RS3-fed animals was the result of a small increase in cell proliferation that was limited to the crypt base of the distal colon. In this experiment, an intake of the two RS3 products over a period of $25 \mathrm{~d}$ was sufficient to achieve altered homeostasis of the colonic mucosa. The slightly decreased number of Ki-67-labelled cells can be interpreted as a normal, butyrate-controlled rate of proliferation.

Butyrate performs several distinct functions in intestinal cells and in particular is the preferred fuel for the distal colonocytes (Roediger, 1982; Topping \& Clifton, 2001). A sufficiently high butyrate concentration in the distal colon is therefore considered to be essential for maintaining colonic health. Butyrate also modulates the expression of many genes by inhibiting histone deacetylation in a complex manner (Blottière et al. 2003; Merchant et al. 2003) including enzymes and proteins, which protect the integrity of the epithelial barrier.

The surface of the distal colon is continuously exposed to dietary antigens and products of microbial metabolism. An intact epithelial barrier function is therefore necessary to prevent the passage of bacteria, endotoxins and other toxic substances from the lumen into the mucosa. A loss of barrier function initiates mucosal inflammation and injury. A preventive effect on the colonic surface may also result from stimulation of the colonic transit time by high SCFA concentrations (Fukumoto et al. 2003).

Considering these butyrate-mediated beneficial effects, it can be concluded that HMT-Novelose fulfils the function of a butyrogenic prebiotic substrate better than Novelose 330 . 
The modified Novelose 330 may therefore be recommended as the source of an excellent prebiotic RS3 for producing functional food in industry.

\section{Acknowledgements}

The authors thank Professor Dr G. Damaschun, Max-Dellbrück-Centrum Berlin-Buch, Germany, for performing the X-ray analyses and Bärbel König, Karin Richter and Horst Maischack for excellent technical assistance. Dr Christopher Seal (School of Agriculture, Newcastle upon Tyne, UK) is thanked for his helpful comments and for correcting the manuscript.

\section{References}

Abadie C, Hug M, Kübli C \& Gams N (1994) Effect of cyclodextrins and undigested starch on the loss of chenodeoxycholate in the faeces. Biochem J 299, 725-730.

Andoh A, Tsujikawa T \& Fujiyama Y (2003) Role of dietary fiber on short-chain fatty acids in the colon. Curr Pharm Des 9, 347-358.

Asp NG, van Amelsvoort JMM \& Hautvast JGAJ (1996) Nutritional implications of resistant starch. Nutr Res Rev 9, 1-31.

Barcenilla A, Pryde SE, Martin JC, Duncan SH, Stewart CS, Henderson C \& Flint HJ (2000) Phylogenetic relationships of butyrate-producing bacteria from the human gut. Appl Environ Microbiol 66, 1654-1661.

Bartram HP, Englert S, Scheppach W, Dusel G, Richter F, Richter A \& Kasper H (1994) Antagonistic effects of deoxycholic acid and butyrate on epithelial cell proliferation in the proximal and distal colon. Z Gastroenterol 32, 389-392.

Blottière HM, Buecher B, Galmiche JP \& Cherbut C (2003) Molecular analysis of the effect of short-chain fatty acids on intestinal cell proliferation. Proc Nutr Soc 62, 101-106.

Büttcher V, Welsh T, Willmitzer LS \& Kossmann J (1997) Cloning and characterization of the gene for amylosucrase from Neisseria polysaccharea: production of linear $\alpha-1,4$-glucan. $J$ Bacteriol 179, 3324-3330.

Cherbuy C, Andrieux C, Honvo-Houeto E, Thomas M, Ide C, Druesne N, Chaumontet C, Darcy-Vrillon B \& Duee PH (2004) Expression of mitochondrial HGMCoA synthase and glutaminase in the colonic mucosa is modulated by bacterial species. Eur J Biochem 271, 87-96.

Christl SU, Bartram HP, Paul A, Kelber E, Scheppach W \& Kasper H (1997) Bile acid metabolism by colonic bacteria in continuous culture: effects of starch and $\mathrm{pH}$. Ann Nutr Metab 41, 45-51.

Dongowski G, Huth M \& Gebhardt E (2003) Steroids in the intestinal tract of rats are affected by dietary-fibre-rich barley-based diets. $\mathrm{Br}$ J Nutr 90, 895-906.

Eerlingen RC, Jacobs H \& Delcour JA (1994) Enzyme-resistant starch. V. Effects of retrogradation of waxy starch on enzyme susceptibility. Cereal Chem 71, 351-355.

Eerlingen RC \& Delcour JA (1995) Formation analysis, structures and properties of type III enzyme resistant starch. J Cereal Sci 22, 129-138.

Englyst HN, Kingman SM \& Cummings JH (1992) Classification and measurement of nutritionally important starch fractions. Eur J Clin Nutr 46, S33-S50.

Fukumoto S, Tatewaki M, Yamada T, Fujimiya M, Mantyh C, Voss M, Eubanks S, Harris M, Pappas TN \& Takahashi T (2003) Short-chain fatty acids stimulate colonic transit via intraluminal 5-HT release in rats. Am J Physiol Regul Integr Comp Physiol 284, R1269-R1276.
Gernat C, Radosta S, Anger H \& Damaschun G (1993) Crystalline parts of three different conformations detected in native and enzymatically degraded starches. Starch/Stärke 45, 309-314.

Gidley MJ, Cooke D, Darke AH, Hoffmann RA, Russell AL \& Greenwell P (1995) Molecular order and structure in enzyme resistant retrograded starch. Carbohydr Polym 28, 23-31.

Glinghammar B, Inoue H \& Rafter JJ (2002) Deoxycholic acid causes DNA damage in colonic cells with subsequent induction of caspases, COX-2 promoter activity and the transcription factors NF-кB and AP-1. Carcinogenesis 23, 839-845.

Iacomino G, Tecce MF, Grimaldi C, Tosto M \& Russo GL (2001) Transcriptional response of a human colon adenocarcinoma cell line to sodium butyrate. Biochem Biophys Res Commun 285, $1280-1287$.

Lehmann U, Jacobasch G \& Schmiedl D (2002) Characterization of resistant starch type III from banana (Musa acuminata). J Agric Food Chem 50, 5236-5240.

Lehmann U, Rössler C, Schmiedl D \& Jacobasch G (2003) Production and physicochemical characterization of resistant starch type III derived from pea starch. Nahrung/Food 47, 60-63.

Macfarlane GT \& Cummings JC (2002) Diet and the metabolism of intestinal bacteria. In Food Allergy and Intolerance, pp. 321-341 [J Brostoff and SJ Challacombe, editors]. London: Elsevier Science.

McCullough JS, Ratcliffe B, Mandir N, Carr KE \& Goodlad RA (1998) Dietary fibre and intestinal microflora: effects on intestinal morphometry and crypt branching. Gut 42, 799-806.

Merchant JL, Bai L \& Okada M (2003) ZBP-89 mediates butyrate regulation of gene expression. J Nutr 133, 2456S-2460S.

Pfannemüller B (1987) Influence of chain length of short monodisperse amyloses on the formation of A- and B-type X-ray diffraction patterns. Int J Biol Macromol 9, 105-108.

Ranhotra GS, Gelroth JA \& Glaser BK (1996) Energy value of resistant starch. J Food Sci 61, 453-455.

Reddy BS (1981) Dietary fat and its relationship to large bowel cancer. Cancer Res 41, 3700-3705.

Roediger WEW (1982) Utilization of nutrients by isolated epithelial cells of the rat colon. Gastroenterology 83, 424-429.

Rössler C, Jacobasch G, Schmiedl D \& Gebhardt E (2002) Resistente Stärke Typ 3 aus Roggenstärke, ein funktionelles Lebensmittel [Resistant starch type 3 from rye, a functional food]. Ernährung/ Nutrition 26, 297-305.

Schmiedl D, Bäuerlein M, Bengs H \& Jacobasch G (2000) Production of heat-stable, butyrogenic resistant starch. Carbohydr Polym 43, 183-193.

Sembries S, Dongowski G, Jacobasch G, Mehrländer K, Will F \& Dietrich H (2003) Effects of dietary fibre-rich juice colloids from apple pomace extraction juices on intestinal fermentation products and microbiota in rats. Br J Nutr 90, 607-615.

Siavoshian S, Segain JP, Kornprobst M, Bonnet C, Cherbut C, Galmiche JP \& Blottiere HM (2000) Butyrate and trichostatin A effects on the proliferation/differentiation of human intestinal epithelial cells: induction of cyclin D3 and p21 expression. Gut 46, 507-515.

Spahn TW \& Kucharzik T (2004) Modulating the intestinal immune system: the role of lymphotoxin and GALT organs. Gut 53, $456-465$.

Stute R (1992) Hydrothermal modification of starches: the difference between annealing and heat/moisture-treatment. Starch/Stärke 44, 205-214.

Tabuchi Y, Arai Y, Kondo T, Takeguchi N \& Asano S (2002) Identification of genes responsive to sodium butyrate in colonic epithelial cells. Biochem Biophys Res Commun 293, 1287-1294.

Topping DL \& Clifton PM (2001) Short-chain fatty acids and human colonic function: roles of resistant starch and nonstarch polysaccharides. Physiol Rev 81, 1031-1064.

Velázquez OC, Lederer HM \& Rombeau JL (1996a) Butyrate and the colonocyte, implications for neoplasia. Dig Dis Sci 41, 727-739. 
Velázquez OC, Seto RW, Bain AM, Fisher J \& Rombeau JL (1997) Deoxycholate inhibits in vivo butyrate-mediated BrDU labelling of the colonic crypt. J Surg Res 69, 344-348.

Velázquez OC, Seto RW \& Rombeau JL (1996b) The scientific rationale and clinical application of short-chain fatty acids and medium-chain triacylglycerols. Proc Nutr Soc 55, 49-78.

Wright NA \& Alison M (1984) The Biology of Epithelial Cell Populations. Oxford: Clarendon Press.
Wu HCH \& Sarko A (1978) The double-helical molecular structure for crystalline B-amylose. Carbohydr Res 61, 7-25.

Zambell KL, Fitch MD \& Fleming SE (2003) Acetate and butyrate are the major substrates for de novo lipogenesis in rat colonic epithelial cells. J Nutr 133, 3509-3515.

Zhang F, Subbaramaiah K, Altorki N \& Dannenberg AJ (1998) Dihydroxy bile acids activate the transcription of cyclooxygenase-2. Am Soc Biochem Molec Biol 273, 2424-2428. 